\section{Dragon's Blood Sap (Croton Lechleri) As Storage Medium For Avulsed Teeth: In Vitro Study Of Cell Viability}

Christine Men Martins, Elizane Ferreira Hamanaka, Thayse Yumi Hoshida, Ana Maria Sell, Mirian Marubayashi Hidalgo, Catarina Soares Silveira, Wilson Roberto Poi
Department of Surgery and Integrated Clinics, School of Dentistry of Araçatuba, UNESP - Univ Estadual Paulista, Araçatuba, SP, Brazi

Correspondence: Prof. Dr. Wilson Roberto Poi, Rua José Bonifácio, 1193, 16015-050, Araçatuba, SP, Brasil. Tel: +55-18-3636-3240. e-mail: poi@foa.unesp.br
Tooth replantation success depends on the condition of cementum periodontal ligament after tooth avulsion; which is influenced by storage medium. The dragon's blood (Croton lechleri) sap has been suggested as a promising medium because it supports collagen formation and exhibits healing, anti-inflammatory and antimicrobial properties. Thus, the aim of this study was to evaluate the efficacy of dragon's blood sap as a storage medium for avulsed teeth through evaluation of functional and metabolic cell viability. This in vitro study compared the efficacy of different storage media to maintain the viability of human peripheral blood mononuclear and periodontal ligament cells. A 10\% dragon's blood sap was tested while PBS was selected as its control. Ultra pasteurized whole milk was used for comparison as a commonly used storage medium. DMEM and distilled water were the positive and negative controls, respectively. The viability was assessed through trypan blue exclusion test and colorimetric MTT assay after 1, 3, 6, 10 and $24 \mathrm{~h}$ of incubation. The dragon's blood sap showed promising results due to its considerable maintenance of cell viability. For trypan blue test, the dragon's blood sap was similar to milk $(p<0.05)$ and both presented the highest viability values. For MTT, the dragon's blood sap showed better results than all storage media, even better than milk $(p<0.05)$. It was concluded that the dragon's blood sap was as effective as milk, the gold standard for storage medium. The experimental sap preserved the membrane of all cells and the functional viability of periodontal ligament cells.
Key Words: croton, tooth avulsion, cell viability, tooth replantation

\section{Introduction}

Dental trauma represents a high percentage of dental emergency care in hospitals and an increasing problem in public health (1). Avulsion corresponds to $16 \%$ to $25 \%$ of all traumas in permanent dentition $(1,2)$. Although immediate tooth replantation is the ideal treatment to preserve the periodontal ligament cells (2), delayed tooth replantation is the most common approach conducted (3). The success of tooth replantation depends on the integrity of periodontal ligament cells; which is strongly influenced by storage medium, extra-alveolar period and root preservation (2-5).

Milk is considered gold standard as storage media for avulsed teeth and is strongly recommended by International Association of Dental Traumatology (2-5). Even though, alternative storage media should be suggested, including natural substances (6) and medicinal plants as a function of its diversity, flexibility, accessibility, availability and wide acceptance. Furthermore, the World Health Organization stated that medicinal plants are the best and largest source of drugs for humanity. In this sense, the dragon's blood sap (Croton lechleri) can be suggested as an alternative storage medium within biological principles. However, there is a lack of information about its efficacy to preserve cell viability.
Previous studies have demonstrated significant chemical and pharmacological properties $(7,8)$ of dragon's blood sap such as anti-inflammatory (9), healing (10), anticancer (10-14), antimycotic, antiviral, antifungal and antibacterial $(11,12,15,16)$, and antioxidant $(14,17,18)$ activities. In addition, this sap demonstrated potential to enhance osteogenesis, mineralization and bone formation (19). The substance is also indicated for collagen formation (10) and treatment of digestive disorders, fevers, bleeding, stomach ulcers and wounds $(20,21)$.

By the way, dragon's blood can be applied in the oral cavity, as an alternative treatment for oral cancers and herpes, on the wound healing after implants, reducing inflammatory in cases of periapical lesion and as a storage media for avulsed teeth. Although interesting properties of dragon's blood sap have been described in the literature, there is a lack of in vitro studies using this substance in oral cavity, as well as a storage medium for avulsed teeth in order to obtain successful results.

Thus, the aim of this study was to evaluate the efficacy of dragon's blood sap as storage medium for avulsed teeth through analysis of functional and metabolic cell viability. 
The null hypothesis tested was that the performance of dragon's blood as storage media is better than the gold standard milk.

\section{Material and Method}

The research was approved by the institutional Human Research Ethics Committee (CAAE protocol 0230.0.093.00011).

The following media were tested: dragon's blood sap, phosphate buffered saline (PBS), Dulbecco's Modified Eagle'ss medium (DMEM), milk and water. The dragon's blood sap was provided by MA Soares Marin Farmácia de Manipulação (Porto Velho, RO, Brazil) and then diluted to $10 \%$ in PBS to obtain the experimental medium. Ultra pasteurized whole milk was used (Parmalat Indústria e Comércio de Laticínios LTDA, Jundiaí, SP, Brazil).

The viability of human peripheral blood mononuclear (PBMCs) and human periodontal ligament cells was checked through trypan blue exclusion test and colorimetric MT assay.

The PBMCs were obtained from $15 \mathrm{~mL}$ of venous blood from four healthy donors collected aseptically in heparinized tubes with 2 drops of ACD (anticoagulant $\therefore$ citrate dextrose). The cells were separated according to the modified method of Böyum (22). The tubes were centrifuged at $1500 \mathrm{rpm}$ during $15 \mathrm{~min}$ at room temperature, the interface between erythrocytes and plasma (leucocytes) was diluted in $6 \mathrm{~mL}$ of sterile PBS and then deposited in $2 \mathrm{~mL}$ of a discontinuous gradient of Histopaque ${ }^{\circledR}$ (Sigma Chemical Co., St. Louis, MO, USA) with density of 1.076. After centrifuging at $2000 \mathrm{rpm}$ during $20 \mathrm{~min}$, the leucocytes ring was removed with a Pasteur pipette and transferred to another tube. A total of 3 washings with $8 \mathrm{~mL}$ of PBS were conducted after centrifuging at $1500 \mathrm{rpm}$ during $10 \mathrm{~min}$ and discarding the supernatant. The cells were resuspended in PBS to concentration of $1 \times 107$ cells $/ \mathrm{mL}$.

The human periodontal ligament cells were provided by the Laboratory of Applied Virology of the Federal University of Santa Catarina. The cells were thawed and placed into an incubator $\left(5 \% \mathrm{CO}_{2} / 95 \%\right.$ humidity, 37 ${ }^{\circ} \mathrm{C}$ ) in cell culture bottles (TTP-Techno Plastic Products, Trasadingen, Swiss) containing DMEM (Cultilab, Campinas, SP, Brazil) supplemented with 10\% of fetal bovine serum (SFB; Cultilab) and $1 \%$ of an association of penicillin 10.000 $\mathrm{UI} / \mathrm{mL}$, streptomycin $20 \mathrm{mg} / \mathrm{mL}$ and amphotericin B $2 \mathrm{mg} / \mathrm{L}$ (PSA; Cultilab). The culture medium was replaced every 48 or $72 \mathrm{~h}$. Trypsinization was done after cell confluence, which means that the cells were washed twice with sterile PBS and then incubated with 0.25\% trypsin-EDTA (Sigma Chemical Co., St. Louis, MO, USA) for cell detachment. After neutralization with DMEM, the cell precipitate was washed, dissolved in fresh culture medium and distributed into several bottles. Each trypsinization resulted in a new passage and confluent cells were replicated throughout the experiment so appropriated conditions of viability were maintained - around 10 to 14 passages. To conduct the viability test using human periodontal ligament cells, after trypsinization, the cells were resuspended and the cell concentration was adjusted for each experimental design.

For trypan blue exclusion test, the cell concentration was $1 \times 10^{6}$ cells $/ \mathrm{mL}$ in a total volume of $500 \mu \mathrm{L}$ for each medium. The tubes were incubated at room temperature during $24 \mathrm{~h}$ and the samples were analyzed after 1, 3, 6, 10 and $24 \mathrm{~h}$. Cell viability was tested 4 times for each storage medium. The viability was determined through microscopic analysis of the cells excluded by trypan blue staining, a vital dye derivative of toluidine. Part of each sample was placed in a Neubauer chamber with equal volume of dye. Stained cells or those presenting ballooning degeneration were assumed as dead. Three examiners conducted the analyses and the results were shown in percentage.

For tetrazolium dye colorimetric assay (MTT), the wells were washed three times in PBS to avoid false results due to sap coloration. The periodontal ligament cells were resuspended to $1 \times 10^{4}$ cells $/ \mathrm{mL}$, diluted in $200 \mu \mathrm{L}$ of DMEM supplemented with $10 \%$ of fetal bovine serum and 1\% PSA and then placed in 96 well cell culture plates (TP-Techno Plastic Products, Trasadingen, Swiss). After incubation (5\% $\mathrm{CO}_{2}, 95 \%$ humidity, $37^{\circ} \mathrm{C}$ ) for $24 \mathrm{~h}$ for cell adhesion, DMEM was removed and $200 \mu \mathrm{L}$ of each specific test medium was added. After each incubation period $(1,3,6,10$ and 24 h), the storage medium was removed and $50 \mu \mathrm{L}$ of MTT solution $(5 \mathrm{mg} / \mathrm{mL}$, MTT-thiazole blue, TP-Techno Plastic Products) was added for each $150 \mu \mathrm{L}$ of DMEM in each well. The cell culture plates were incubated for $3 \mathrm{~h}$ and, then, the medium containing MT was removed and $150 \mu \mathrm{L}$ of dimethyl sulfoxide (DMSO; Merck, Rio de Janeiro, RJ, Brazil) was added to dissolve the formazan crystals. Cell viability was calculated through reading of absorbance of each well content using a microplate reader (ASYS Expert Plus Microplate Reader, Biochrom, Reino Unido) with wavelength of $550 \mathrm{~nm}$. The test was conducted in triplicate and 4 repeated measurements were obtained for each medium. Data of percentage of live cells obtained with trypan blue exclusion test were collected for each group over time. For analysis of the results, linear mixed-effects models were used in association with the PROC NLMIXED procedure of the software SAS version 9.

The results obtained with MTT assay were submitted to factorial ANOVA using the software SAS 9.3.n. Significance level of 5\% was used in all analyses.

\section{Results}

Figure 1 shows the means of cell viability for each 
storage medium regardless time. In "A", the results of trypan blue exclusion test are presented as "A1" for PBMCs and "A2" for periodontal ligament cells. The dragon's blood sap presented viability mean of $77 \%$, slightly lower than milk $(87 \%)(p<0.05)$; regardless cell type. PBS and DMEM presented different means comparing cell types and showed lower viability for PBMCs (PBS: 59\%, DMEM: 53\%) than periodontal ligament cells (PBS: 75\%, DMEM: $81 \%)$. However, no statistical significance was found. For periodontal ligament cells, water showed statistically significant difference $(p<0.05)$ in comparison to all media. " $B$ " shows the values of optical density resultant from MTT assay with periodontal ligament cells. Dragon's blood sap presented statistically significant difference $(p<0.05)$ in comparison to all media. PBS and water showed extremely low means of 0.3 and 0 , respectively.

Considering period of incubation, Figure 2 shows the viability of cells stored in different media for 24 fours. In " $A$ ", the results of trypan blue exclusion test are presented as "A1" for PBMCs and "A2" for periodontal ligament cells. The dragon's blood sap exhibited a homogeneous performance over $24 \mathrm{~h}$ with viability values similar to PBS and DMEM for periodontal ligament cells but better conditions for PBMCs $(p<0.05)$. Milk showed better results and statistically significant difference $(p<0.05)$ in comparison to other media after $24 \mathrm{~h}$ only for periodontal ligament cells. Water presented statistically significant difference $(p<0.05)$ after the first hour of incubation. The values of optical density resultant from MTT assay with periodontal ligament cells shown in "B" demonstrate better functional performance of dragon's blood sap than other media, with increasing values over time. This group presented statistically significant difference $(p<0.05)$ in comparison to PBS and water after $1 \mathrm{~h}$, DMEM after $6 \mathrm{~h}$ and milk after $24 \mathrm{~h}$.

Figure 3 shows the analysis of means of percentage viability at different periods of incubation. In "A", the results of trypan blue exclusion test are presented as "A1" for PBMCs and "A2" for periodontal ligament cells. The results revealed decreasing viability over time and statistically significant difference $(p<0.05)$ among all periods of incubation. The MTT results in "B" showed that the viability of periodontal ligament cells was maintained up to $10 \mathrm{~h}$ and statistically significant difference $(p<0.05)$ was found for the results measured after $24 \mathrm{~h}$.

\section{Discussion}

Based on the results presented the null hypothesis is accepted, so the performance of dragon's blood as storage media is better than the gold standard milk.

Replantation of avulsed teeth is important for its reinsertion into dental alveolus but a delayed procedure is usually conducted (4). Thus, periodontal ligament cells must be preserved $(2,3,5)$ with a storage medium that presents appropriate chemical and pharmacological properties for replant success $(3,4)$. In this sense, previous studies have found that the dragon's blood sap has anti-inflammatory, antimicrobial and healing properties that are essential for this treatment approach $(9,10,15,16,19)$.

In the present study, the PBMCs were used because they are readily obtained while the periodontal ligament cells were tested to simulate a real scenario as they are strongly affected by tooth replantation. Furthermore, standardization of cell concentration in culture of PBMCs
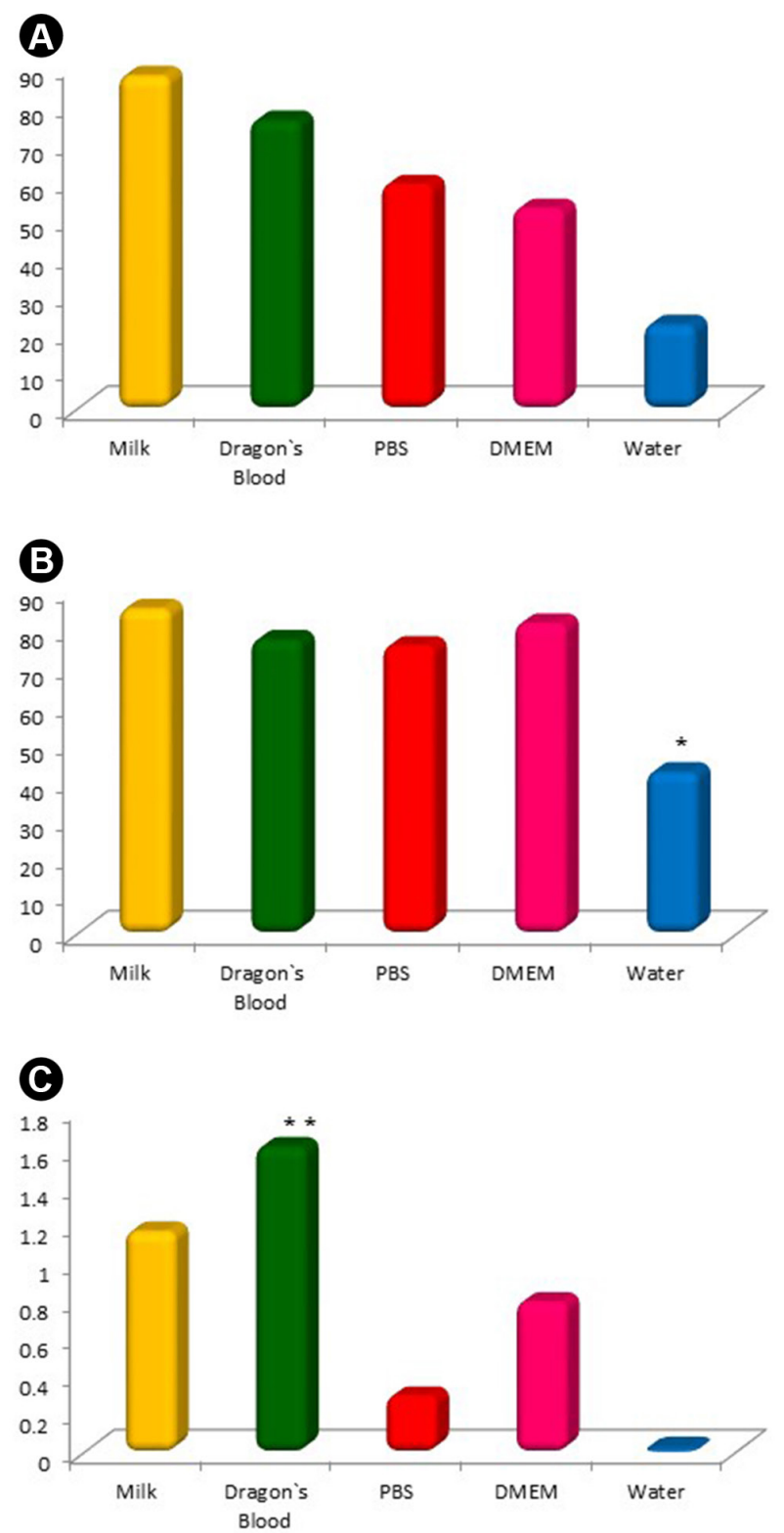

Figure. 1. Means of cell viability for different storage media. A: trypan blue exclusion test: A1: PBMC, A2: periodontal ligament cells. B: MTT assay. *Statistically significant difference $(\mathrm{p}<0.0001)$ of water in comparison to other media; ${ }^{* *}$ Statistically significant difference $(\mathrm{p}<0.0001)$ of dragon's blood sap in comparison to other media. Experiments were repeated 4 times in triplicate. 
and fibroblasts allows evaluation of random variations. The experimental periods of incubation also simulated clinical scenario of delayed tooth replantation and was based on previous study (25).

The viability test using trypan blue provides information about physical integrity of cell membrane (22) but it does not evaluate real metabolic cell activity. Thus, this condition was measured by MTT assay through quantification of
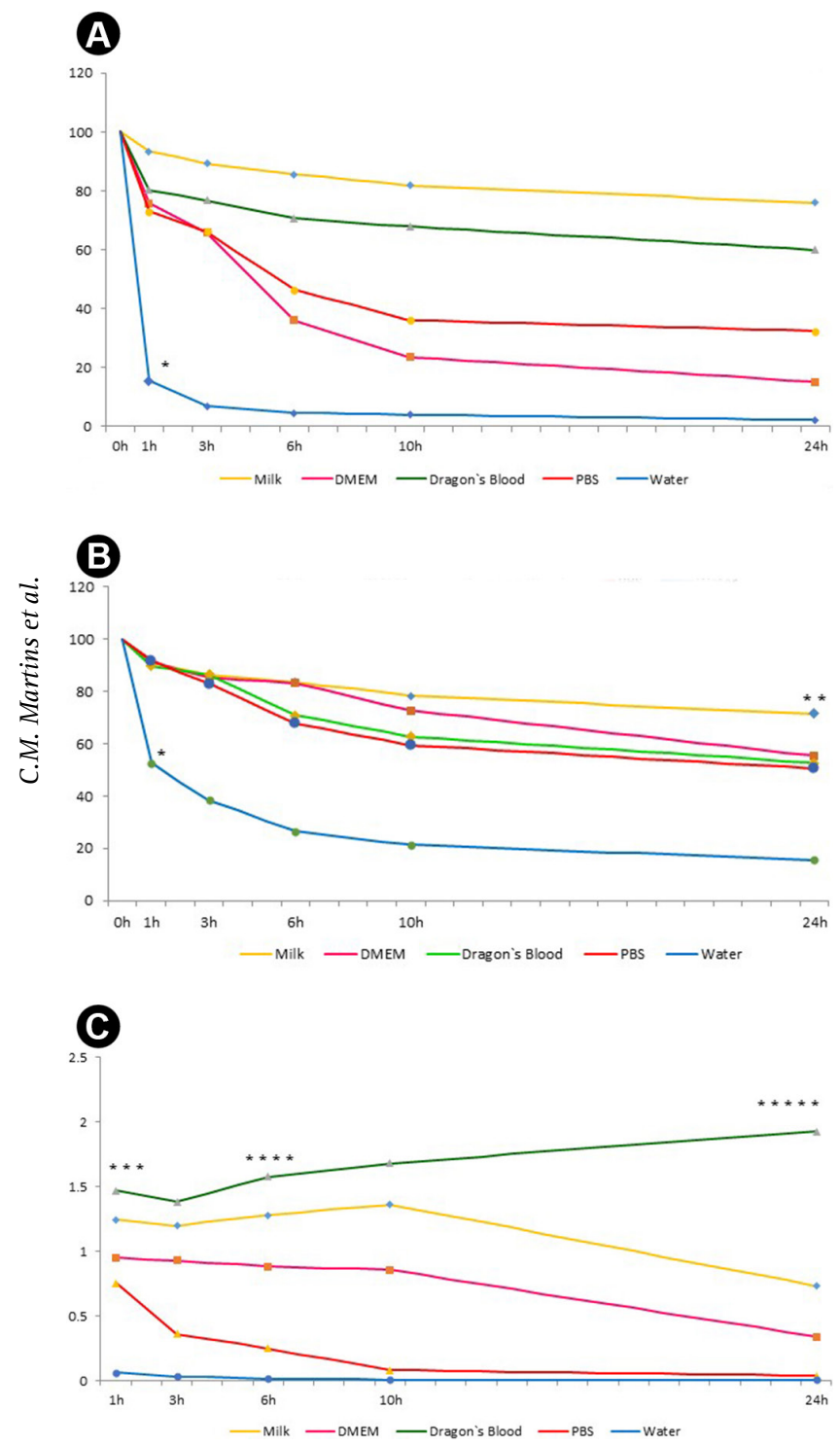

Figure. 2. Relative percentage of cell viability means in different storage media over time. A: trypan blue exclusion test: A1: PBMC, A2: periodontal ligament cells. B: MTT assay. *Statistically significant difference $(p<0.0001)$ of water in comparison to other media after the first hour of incubation; ${ }^{* *}$ Statistically significant difference $(p<0.0001)$ of milk in comparison to other media; ${ }^{* * *}$ Statistically significant difference $(\mathrm{p}<0.0001)$ of dragon's blood sap in comparison to PBS and water after the first hour of incubation; ${ }^{* * * * *}$ Statistically significant difference ( $p<0.0001)$ of dragon's blood sap in comparison to DMEM after $6 \mathrm{~h}$ of incubation; ******Statistically significant difference $(p<0.0001)$ of dragon's blood sap in comparison to milk. Experiments were repeated 4 times in triplicate for MTT.
MTT reduction (water-soluble yellow salt) into formazan (insoluble purple salt) by NADPH-dependent enzymes. As a consequence, $\mathrm{MTT}$ reduction into formazan is proportional to mitochondrial activity and functional viability of the cells (25).

The results showed that the good properties of dragon's blood sap preserve cell viability. In trypan blue exclusion test, the dragon's blood sap was similar to milk $(\mathrm{p}<0.05)$ and both showed the highest viability values (Figs. 1, A1 and A2). For MT assay, the experimental medium was superior to all media; including milk $(\mathrm{p}<0.05)$ (Fig. 1B). The sap
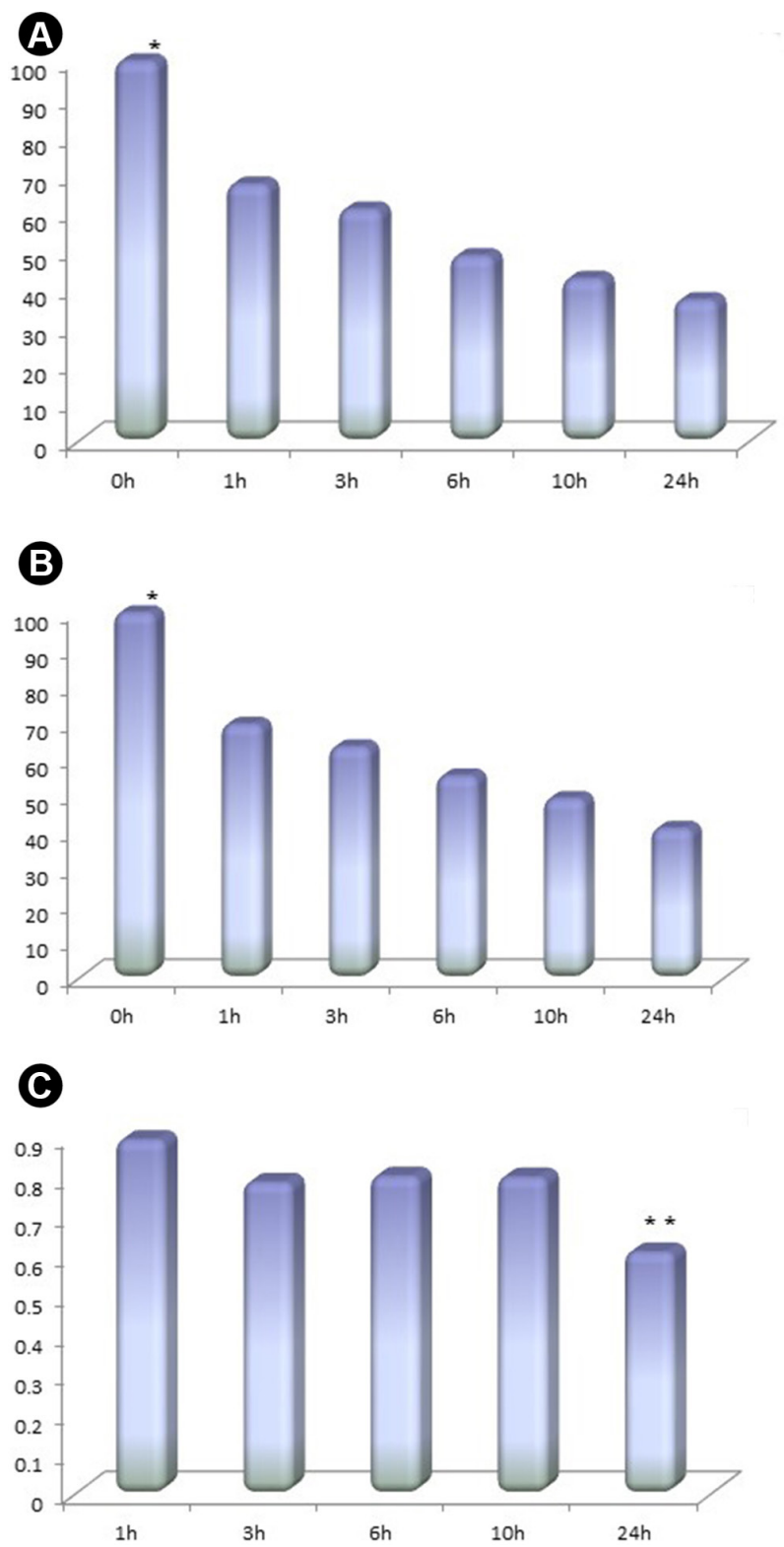

Figure. 3. Means of cell viability over time. A: trypan blue exclusion test: A1: PBMC, A2: periodontal ligament cells. B: MTT assay. *Statistically significant difference $(\mathrm{p}<0.0001)$ among all periods of incubation; ${ }^{* *}$ Statistically significant difference $(\mathrm{p}<0.0001)$ after 24 $\mathrm{h}$ of incubation in comparison to other periods. Experiments were repeated 4 times in triplicate for MTT. 
exhibited homogeneous performance over time and values similar to milk (Fig. 2, A1 and A2). In MT assay, increasing optical density was found over time (Fig. 2B). This can be supported by the good properties of dragon's blood sap, regarding to good biocompatibility and antioxidant effect presented, as demonstrated by O'Brien (1994) in his study of antioxidants presented by this medicinal plant (14).

Considering data of media regardless period of incubation, the dragon's blood sap presented good results for different cell types and performance similar to milk and DMEM $(p<0.05)$ in trypan blue exclusion test while the sap was better than all media in MTT assay. This finding means that cell membrane and functional viability were preserved. Considering the periods of incubation in trypan blue exclusion test, the sap maintained cell viability homogeneously and no difference was found in comparison to milk and positive control with both cell types, except for periodontal ligament cells after $24 \mathrm{~h}$ of incubation.

Some studies reported that the dragon's blood sap presents phenolic compounds, such as taspine alkaloid; that favors healing, fibroblasts chemiotaxy and antiinflammatory activity $(15,23)$. As a consequence, it can be suggested that this compound preserves cell viability. In MTT, the dragon's blood sap showed increased optical density over time with statistically significant difference in comparison to all media. This surprisingly result may suggest cell proliferation or increased metabolic activity, which is in accordance with Wang et al. (19), who evaluated the effect of dragon's blood sap on cell differentiation, mineralization and cell proliferation of osteoblasts and found that the sap influenced cell proliferation during 25 days. Another hypothesis could be the production and/or release of mediators or growth factors by cells in contact with the sap since the previous study demonstrated increased cell activity for 15 days after using the compound.

Although the natural and simple method of extraction could result in microbial contamination of the sap, this problem was not observed probably because the proantocianidines found in the tree bark and extract have antimicrobial activity $(10,12,15,16)$.

It was difficult to conduct microscopic analysis because sap color and viscosity are heterogeneous and similar to blood. Thus, after several microscopic tests with serial dilutions, sap dilution in PBS to 10\% was chosen as a clear and safe alternative.

PBS is a phosphate-buffered solution similar to saline that presents ideal osmolarity and $\mathrm{pH}$ but no ions and glucose are present to maintain cell activity $(5,24)$. Cell viability with PBS was similar to the dragon's blood sap in trypan blue exclusion test but different in MT assay. This result was observed because the trypan blue test reveals cell membrane integrity only and no metabolic cell activity is measured. Thus, the biocompatibility of PBS preserved the physical integrity of cells but they were not active. It is also noteworthy that the dragon's blood sap contained $10 \%$ of natural sap and $90 \%$ of PBS in the present study; which means that only $10 \%$ of sap was enough to preserve cell viability (Figs. 1B, $2 \mathrm{~A} 1$ and $2 \mathrm{~B}$ ).

The milk was used in this research as a comparative medium because it is an isotonic liquid with little bacteria that presents approximately neutral $\mathrm{pH}$ and physiological osmolarity and contains growth factors and nutrients essential to cells $(4,5)$. Currently, milk is widely accepted as an appropriate storage medium that preserves the viability of periodontal ligament cells.

DMEM was used as the positive control medium of cell culture that reduces damage to cells and enhances cell proliferation (25). However, the results showed decreased cell viability in this medium probably because the experiment was conducted at room temperature to simulate real scenario and the ideal conditions of incubation $\left(5 \% \mathrm{CO}_{2}, 95 \%\right.$ humidity and $\left.37^{\circ} \mathrm{C}\right)$ were not maintained.

Water was selected as the negative control storage medium for avulsed teeth because it exhibits microbial contamination, hipotonicity, and $\mathrm{pH}$ and osmolarity over physiological limit that causes cell lysis (25). As a consequence, both tests demonstrated a negative effect of water on cell viability after the first hour of incubation.

The limitations of this study is using low concentration of Dragon's blood sap, as well it was only conducted an in vitro study with two cell types and it was analyzed only functional and metabolic cell viability. At this point, it is important to evaluate the others parameters of this substance to validate its use as storage media for avulsed teeth.

Considering the periods of incubation, cell integrity decreased over time and functional activity was maintained up to $10 \mathrm{~h}$ with statistically significant difference in comparison to $24 \mathrm{~h}$ of incubation. However, the dragon's blood sap preserved cell viability up to $24 \mathrm{~h}$. Data in function of time should be carefully interpreted since replantation of avulsed teeth must be done as quickly as possible (5). Thus, immediate replantation should be addressed in association with appropriate storage medium and root preservation to provide success of replantation of avulsed teeth (2-5).

It was concluded that the dragon's blood sap was an efficient storage medium for avulsed teeth since it preserved membrane integrity of different cell types and maintained functional viability of periodontal ligament cells.

\section{Resumo}

0 sucesso do reimplante dentário depende da condição apresentada pelo ligamento periodontal cementário pós-avulsão que pode ser influenciado pelo meio de estocagem. O Sangue de Dragão (Croton lechleri) é sugerido 
como um meio promissor por auxiliar na formação de novo colágeno e apresentar propriedades cicatrizante, anti-inflamatória, antimicrobiana. Assim, o objetivo deste trabalho foi avaliar a eficácia da seiva Sangue de Dragão como meio de estocagem para dentes avulsionados por meio da aferição da viabilidade funcional e metabólica celular. Este estudo in vitro comparou a eficácia dos meios para a manutenção da viabilidade das células mononucleares de sangue periférico humano e do ligamento periodontal mantidas em cultura. Foi testada a diluição a $10 \%$ da seiva Sangue de Dragão enquanto que a PBS foi selecionada como seu controle. 0 leite ultrapasteurizado integral foi utilizado como meio comparativo por ser tradicionalmente utilizado como meio de estocagem. 0 DMEM e a água destilada foram os controles positivos e negativos, respectivamente. A avaliação da viabilidade foi feita por meio dos testes de exclusão por Azul de Tripan e colorimétrica a base de tetrazolato (MT), após 1, 3, 6, 10 e $24 \mathrm{~h}$ de incubação. A seiva Sangue de Dragão apresentou resultados promissores devido à sua considerável manutenção da viabilidade celular. Para a metodologia com o Azul de Tripan, a seiva Sangue de Dragão foi semelhante ao leite.

\section{References}

1. Bastone EB, Freer TJ, McNamara JR. Epidemiology of dental trauma: a review of the literature. Aust Dent J 2000;45:2-9.

2. Andersson L, Andreasen JO, Day P, Heithersay G, Trope M, DiAngelis AJ, et al. International Association of Dental Traumatology guidelines for the management of traumatic dental injuries: 2 . Avulsion of permanent teeth. Dent Traumatol 2012;28:88-96.

3. Poi WR, Sonoda CK, Martins CM, Melo ME, Pellizzer EP, Mendonça MR et al. Storage media for avulsed teeth: a literature review. Braz Dent J 2013;24:437-445.

4. Sottovia AD, Sottovia Filho D, Poi WR, Panzarini SR, Luize DS, Sonoda CK. Tooth replantation after use of Euro-collins solution or bovine milk as storage medium: a histomorphometric analysis in dogs. J Oral Maxillofac Surg 2010;68:111-119.

5. Marino T, West LA, Liewehr FR, Mailhot JM, Buxton TB, Runner RR, et al. Determination of periodontal ligament cell viability in long shelf-life milk. J Endod 2000;26:699-702.

6. Li JWH, Vederas JC. Drug discovery and natural products: end of an era or an endless frontier? Science 2009;325:161-165.

7. Gupta D, Bleakley B, Gupta RK. Dragon's blood: botany, chemistry and therapeutic uses. J Ethnopharmacol 2008;115:361-380.

8. Lopes ML, Saffi J, Echeveverrigaray S, Henrique JAP, Salvador M. Mutagenic and oxidant activities of Croton lechleri SAP in biological systems. J Ethnopharmacol 2004,95:437-445.

9. Li YS, Wang JX, Jia MM, Liu M, Li XJi, Tang HB. Dragon's blood inhibits chronic inflammatory and neuropathic pain responds by blocking the synthesis and release of substance $P$ in rats. J Pharmacol Sci 2012;118:43-54.

10. Chen ZP, Cai Y, Phlillipson JP. Studies on the anti-tumor, anti-bacterial, and wound-healing properties of dragon's blood. Planta Med 1994;60:541-545.
11. Alonso-Castro AJ; Ortiz-Sánchez E, Dóminguez F, López-Toledo G, Chávez M, Ortiz-Tello AJ et al. Antitumor effect of Croton lechleri Mull. Arg. (Euphorbiaceae). J Etnopharmacol 2012;140:438-442.

12. Cui JL, Guo SX, Dong H, Xiao P. Endophytic fungi from Dragon's blood specimens: isolation, identification, phylogenetic diversity and bioactivity. Phytoter Res 2011;25:1189-1195.

13. Montopoli M, Bertin R, Chen Z, Bolcato J, Caparrotta L, Froldi G. Croton lechleri sap and isolated alkaloid taspine exhibit inhibition against human melanoma SK23 and colon cancer HT29 celllines. J Etnopharmacol 2012;144:747-753.

14. O'Brien P. Antioxidants and cancer: molecular mechanisms. In: Free radicals in diagnostic medicine. Armstrong $D$ (Editor). New York: Plenum Press;1994. p. 215-p238.

15. Gupta D, Gupta RK. Bioprotective properties of Dragon's blood resin: in vitro evaluation of antioxidant activity and antimicrobial activity. BMC Complement Altern Med 2011:11:13.

16. Luo $Y$, Wang H, Zhao YX, Zeng YB, Shen HY, Dai HF, et al. Cytotoxic and antibacterial flavonoids from Dragon's blood of Dracaena cambodiana. Planta Med 2011;77:2053-2056.

17. Gonzales GF, Valerio LG. Medicinal plants from Peru: a review of plants as potential agents against cancer. Anticancer Agents Med Chem 2006;6:429-444.

18. Jones K. Review of sangue de drago (Croton lechleri) a South American tree sap in the treatment of diarrhea, inflammation, insect bites, viral infections, and wounds: traditional uses to clinical research. J Altern Complement Med 2003;9:877-896.

19. Wang W, Olson D, Cheng B, Guo X, Wang K. Sanguis Draconis resin stimulates osteoblast alkaline phosphatase activity and mineralization in MC3T3-E1 cells. J Etnopharmacol 2012;142:168-174.

20. Mark M, Naughton W, Zhang XJ, Thompsom J, Charbonet R, Bobrowski $P$, et al.. Treatment of gastric ulcers and diarrhea with the Amazonian herbal medicine sangre de grado. Am J Physiol Gastrointes T Liver Physiol 2000;279:192-200.

21. Sandoval M, Okuhama NN, Clark M, Angeles FM, Lao J, Bustamante S, et al. Sangre de grado Croton palanostigma induces apoptosis in human gastrointestinal cancer cells. J Ethnopharmacol 2002;80:121-129.

22. Boyum A. Isolation of mononuclear and granulocytes from human blood. Isolation of mononuclear cells by one centrifugation, and of granulocytes by combining centrifugation and sedimentation at $1 \mathrm{~g}$. Scand J Clin Lab Invest Suppl 1968;97:77-89.

23. Zhang, J, Zhang, Y, Zhang, S. Sicen Wang, Langchong He Discovery of novel taspine derivatives as antiangiogenic agents Bioorg Med Chem Lett 2010;20:718-721.

24. Martin MP, Pileggi, RA. A quantitative analysis of Propolis: a promising new storage media following avulsion. Dent Traumatol 2004;20:85-89.

25. Casaroto AR, Hidalgo MM, Sell AM, Franco SL, Cuman RKN, Moreschi E, et al.. Study of the effectiveness of propolis extract as a storage medium for avulsed teeth. Dental Traumatol 2010;26:323-331.

Received May 4, 2016

Accepted September 13, 2016 